\title{
Popular Landscape of Entertainment in East-Central Europe, 1850-1939. An Introduction
}

\author{
Izabela Kopania \\ Institute of Art, Polish Academy of Sciences, Warsaw ${ }^{1}$
}

\begin{abstract}
"An outright abundance of amusements. Twenty out of thirty posters announce and praise the spectacles so far unparalleled. In Passage-Panoptikum, the Dahomeys laid out.

I proceeded onwards to catch sight of some more people. (...)

A huge, gilded hall flooded with rays of the sun, crowded and buzzing. Music plays a sentimental waltz. The masses smoke, and speak. White aprons of waiters cross the hall in diverse directions, and one may hear knocks of pitchers and a hoarse voice:

- Beer!

The hall is full of Dahomey. They squeeze between the tables with the dexterity of monkeys and wheedle money. They are almost naked and beautifully built. The black-and-ashen hue of their skin is velvety, glittering and invariably soft. A certain Dahomey Venus simpers and intrusively strives for selling a photograph of her. (...) two enchanters or bonzes wearing white coats came out to the forefront of the stage. One of them holds a monstrous deity, coarsely hewn of wood; and the second - a flat, cane basket and a long pipe made of reed.

- Serpents! A serpent! Die Schlange! - the crowd yells and a strange kind of shiver pierced through everyone. (...)

The snakes stood almost vertically and started to perform a kind of dance along slanting lines. Their long and greenish bodies writhed, bounced and fell on the ground hissing.

There is commotion in the hall, but after a while the crowd erupts in applause, and this European, metropolitan mob is immersed in delight. (...)

Gentlemen! Buy photographs showing the King of Dahomey. Only one mark a piece..." (REYMONT 1894).
\end{abstract}

The foregoing quotation is taken from a reportage authored by Władysław Reymont, a Polish novelist and a 1924 Nobel Prize winner in Literature, published in Warsaw's Kurier Codzienny in 1894. This piece was written in the early years of his work and belongs to a series of Travel Notes documenting his alleged first

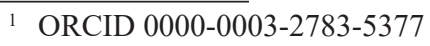


travel abroad. He headed for London in order to participate in a Theosophical Society Congress and visited Berlin, Magdeburg, Köln, Brussels and Ostend along the way (KochanowsKi 2010:185). The fragment cited above was written down in London and is a record of his impressions of Berlin.

Berlin was the first modern city that Reymont visited. Rather bored by the city itself, his attention was focused on shows and spectacles that constituted a part of Berlin popular entertainment theater. Reymont bent his first steps towards the commercial arcades where two panopticons were located: Castan's Ponopticon established in 1873 by brothers Louis and Gustave Castan, as well as the Passage-Panoptikum operating from 1888 onwards (ZIMMERMAN 2001:16). It was in the latter where he witnessed the spectacular performance he later described.

The permanent attraction of both places consisted of collections of wax figures representing historical characters and anatomical statues. Castan's place amazed its visitors with figures representing various ethnic groups while Passage boasted a display of 'abnormalities'. Both sites hosted freak performers and ethnic 'others' on a regular basis. In July, when Reymont arrived in the city, the main attraction of Castan's Panopticon was the "Wild Women of Dahomey"- a show given by a group of Dahomey inhabitants of Western Africa brought to the Old Continent by a Swiss entrepreneur Albert Urbach (CIARLO 2011:97). It was likely the same group that Reymont saw at the Passage-Panoptikum.

Reymont distances himself from the event and the urban crowd, taking the role of an observer. He renders the city as a stage where human actions, social roles and cultural practices come to the forefront. The hall in the Panoptikum is a space which is clearly ordered; filled with the crowd rigidly divided into the audience and the actors. He perceives the Africans as natural and unspoiled while their public betrays the worst human instincts: licentiousness, indulgence and lack of constraints (KocHANOwSKI 2010:190). Reymont's description is organized around a natural/artificial axis and is usually interpreted in terms of an expression of his strong anti-urban attitude (SZTACHELSKA 1997:148).

I began my reflections with this lengthy quotation because it is one of the few preserved accounts of a personal encounter with the 'exotic other'. What Reymont describes is one of numerous forms of entertainment that European cities and towns offered their inhabitants and visitors, which gained new conventions and meanings in the late $19^{\text {th }}$ century, mainly the performances of 'exotic' people in front of the public. On the one hand, his short reportage can be viewed as a source material providing insight into what happened during such an encounter according to one of its crucial agents. On the other, it encapsulates all the treads determining the essence of articles collected in the present volume. The authors deal with both the life of cities, as well as the experience of modernization and encounters with otherness.

The following essays examine types, places and cultural contexts of popular amusements available for urban societies of Central and Eastern Europe. This territory, with its unstable borders and unstable meanings, has been discussed time and again (AsH 1986, 1999; KunDERA 1983). This territory encompasses the historical lands of the Kingdom of Bohemia, the Kingdom of Hungary, as well as the Polish and Lithuanian Commonwealth (KŁoczowsKi 2004). In the period under discussion, roughly covering the years from 1850 to 1939 , numerous significant changes and transformations of geographical, political, economic, social and cultural nature can be observed. This time 
period was 'witness' to rapid development, modernity and the turmoils of the war; it saw progress in science and technology, urbanization and industrialization, as well as the birth of mass culture. Different regions of this vast territory experienced these phenomena in different times and local specificity is addressed in subsequent contributions.

One of the hallmarks of the approaches used by the authors is that they seek to investigate the act of entertainment as a situation where interaction with alterity occurs. Here, the 'other' is a leading agent recurring throughout the entire volume. 'Others' were socially construed figures (sometimes referred to as 'freaks'). Their otherness stemmed from physical features (such as abnormal hair growth), ethnicity or extraordinary bodily constitution (like 'supernatural' strength). ${ }^{2}$ A parade of 'strangeness' moved on in front of the very eyes of the inhabitants of Central and Eastern European cities and towns: women with hypertrichosis (Julia Pastrana, Zenona Pastrana, Krao Farrini), conjoined twins (Chang and Eng Bunker, Rosa and Josepha Blažek), albinos, parasitic twins, dwarfs and giants, American Indians, Nubians and Dahomey from Africa, the Sinhalese from Ceylon, Chinese and Japanese troupes just to mention a few examples.

Places of popular amusements - fairs, circuses, pleasure gardens, cafés, halls owned or rented by charitable and music societies (where 'freaks' performed and itinerant panopticon museums displayed their collections) - created a social space where the public met people who were placed on display and where the division between 'audience/us' and 'performers/others' was negotiated. The borders between the two groups were never stable. Once they were established by the distance between the stage and auditorium; the other time, it was blurred when actors and show-goers intermingled (like in Reymont's account); they were also mediated by an entrepreneur operating as a person between the two agents. Entertainment sites were places of many exchanges: of gazes, gestures, touches, smells and voices. These were places where meticulously arranged and directed 'lectures' on non-European cultures were delivered and where the audience arrived not only to see 'the wondrous' but also to confirm their notions of the 'norm', which itself was a sociocultural construction. Finally, these were also places of economic transactions, 'buy-pay' deals, as well as the production of cultural artifacts.

Consequently, another important idea behind this collection is that beyond fulfilling the needs of developing urban societies and amusing the masses through entertainment, entertainment sites served important roles in forming social/national/cultural identities. This has already been demonstrated through the example of how freak shows appealed to the concerns of national identity in American society (GARLAND-THOMPSON 2017). Numerous studies have discussed how the processes of 'enfreakment' and 'othering' of the body advanced. The bodies on display also appealed to many other worries and concerns such as sexual (just to mention Sarah Baartman, see QURESHI 2004) but also to those more difficult to determine, built around the binaries of center/periphery, civilized/ uncivilized, human/beast and normal/abnormal.

Last but not least, this collection of essays asks questions about the Central and Eastern European world of knowledge, images and concerns. The authors explore how 'the other/the othered body' functioned within the framework of entertainment culture in Central and Eastern Europe. What new aspects, elements and ideas did the participation

2 As the literature on the subject is abundant, I refer the reader to the following seminal works: Bogdan 1988; GARLAND-ThOMSON 1997; Blanchard et al. 2014. 
of 'exotic others' in entertainment culture offer to the image of the non-European in the eyes of the world(s) not engaged in colonial politics? What traces did the presence of 'others' leave on this image? To what extent did advertising material (such as leaflets, posters, program booklets) produced in the West determine Central and Eastern European views? How were 'our own others' perceived and how was their difference construed? It has been repeatedly demonstrated that there are no direct answers to these questions. Building on these queries, this volume then, also contributes to the complexity of this fascinating and intricate set of problems.

The 'other' as a figure of entertainment in Central and Eastern Europe is a relatively uncharted subject within studies on popular culture in the region. It is directly related to the Central European tradition of, among others, ethnographic exhibitions, freak shows, circuses and ethnic shows which during the last few years have seen increased interest among scholars (just to mention a few publications: Filipové 2011; KérCHY - ZitTLAU 2012; HerZA 2016; KUREK - MEYER 2017). The most recent contributions to the filed stem from a research project entitled: Staged Otherness. Human Oddities in Central and Eastern Europe, 1850-19393 (BARANIECKA-OlsZEWSKa 2020; CZARNECKa 2018; DEMSKi 2018) to which the following publication also owes its emergence.

The present volume consists of eleven studies. The collection opens with Andrea Zittlau's contribution: Staged Otherness in American Academia. A Reading. This thorough study provides an outline of theoretical and methodological approaches to 'freaks' and freak shows adopted throughout the decades by American scholars. It was in the context of the Anglo-Saxon world that this subject emerged. Zittlau traces the development of this field from 'popular' or 'journalistic' writings, to disability studies which now constitute the most engaged area of research on 'freaks'. This contribution renders the development historically; involving psychoanalysis, postcolonial studies, as well as literary criticism and popular culture, in order to question the American element of the freak show phenomenon and encourage both a rethinking of its cultural significance, allocating approaches that are applicable to other national/social/cultural contexts.

Izabela Kopania's article also contributes to the field of 'freak show' studies. The author traces and reconstructs the Central and Eastern European odyssey of Julia Pastrana, a famous 'bearded women' whose story lies at the very beginnings of American and continental freak shows, understood in terms of institutionalized entertainment. Kopania focuses on Pastrana's stay in Warsaw and on the reactions of the Polish language press with regards to her unusual body. The author examines the freak show business model, the commodification of Pastrana's body and the cultural responses that her stay in Warsaw provoked. With regards to how her otherness was conceptualized at the eastern borders of Europe, Kopania demonstrates how Pastrana's press image was determined by advertising materials as well as her 'official' biography. The civilized/ uncivilized, male/female and human/beast binaries which constituted the basis of her image in America and Britain were also employed by Polish press reviewers. There were some local traits of Pastrana's perception (such as emphasizing some of her features and silencing others), to a large extent however, her image was created by the well-planned advertising campaign of her husband-impresario Theodore Lent.

\footnotetext{
3 Funding was granted by the National Science Center, Poland (project no 2015/19/B/HS3/02143).
} 
Dagnosław Demski examines the theater of popular entertainment in Gdańsk (Danzig) throughout the years 1860-1914. Mainly drawing on German language press printed in the town then belonging to the German empire, he reconstructs the types of amusements and districts in the town where the amusements in question took place. 'Walking' around the town, Demski visits former places of entertainment as well as the St. Dominic's Fair, focusing on performances given by three groups of Africans during the 1890s: the caravans of Wakamba, Swahili and the so called 'Neger' (an original term). The caravans consisted of authentic tribal groups. They performed traditional roles. However, press descriptions of the shows responded to deeply rooted stereotypes on Africa and Africans reaching as far as early modern climate theories on skin colors.

Kamila Baraniecka-Olszewska and Dominika Czarnecka explore the space of circus. Baraniecka-Olszewska focuses on three visits of the Sarrasani circus in the town of Opole in 1913, 1928 and 1933. This was the period when ethnic shows had already been transformed into circus attractions. Consequently, she describes a situation when ethnographic shows constituted one of many circus acts and focuses on how they were orchestrated to attract viewers by means of commercial tools and dexterous presentations of the 'exotic' as attractive and fascinating; still providing the atmosphere of the unknown. Czarnecka discusses the phenomenon of wrestling fights and strongman shows in the circus arena. She traces the image of 'white' and 'black' wrestlers, as well as showmen, as construed by the Polish press in order to understand the process of consumption of race and masculinity. She observes seminal differences in the press image of 'white' strongmen and their 'black' counterparts. The physical strength of 'white' strongmen was connected to a lack of brutality, as well as the elaborate use of the body, achieved through training and self-control. This was, in turn, perceived as a result of civilizational superiority. On the contrary, 'black' strongmen were often described as 'animal(s)' or 'black beast(s)', lacking constraint and self-control. These characteristics were linked with animal-like behavior within the sphere of the arena at the time. Moreover, their unusual power was perceived as 'natural'; immanent in their physical condition. Czarnecka also demonstrates how the 'exotic' was exoticized within circus practices and how circus entrepreneurs and performers themselves participated in construing the social image of strongmen.

Tímea Barabás examines the career of Gogea Mitu from Romania, who still holds the title of the highest professional boxer in the world. Thus, she focuses on an 'other' who is 'our own', coming from within, not from far away. Mitu began his stage career as a circus performer and transferred into the world of boxing with time. Barabas examines a 'deviant body' invested with symbolic meaning, focusing on the process of how this meaning was attributed to and negotiated. Drawing on press materials, the author identifies metaphoric constructions such as, 'Goliath', 'gentle giant' and 'boxing phenomenon' around which Mitu's image was construed. She also addresses the way Mitu created his own image in accordance with social expectations in order to obtain professional success.

Bartosz Hlebowicz devoted his contribution to a relatively unknown episode from the third European tour of The Buffalo Bill's show (1902-1906): Buffalo Bill's Wild West and Congress of Rough Riders of the World performances in the Polish cities at the very final phase of the tour. Drawing on press articles, Hlebowicz reconstructs the image of "Indians" created by Polish journalists and identifies some unexpected contexts in 
which Buffalo Bill's group was used by the authors. Native Americans were perceived as romantic, static, calm and slowly disappearing; living in some eternal ancient past which was in tune with the "myth' of "an Indian" deeply rooted in both American and European popular culture. Polish journals devoted a lot of space to descriptions of and commentaries on Buffalo Bill's Wild West. It was not uncommon for reviewers to praise the authenticity and educative qualities of the shows, as well as the disciplined staff and the excellent organization of events. The performances, however, were also entangled in political struggles and nationalistic controversies. Anti-Semitic press continually criticized the shows and their director and accused him of inauthenticity and cheating. The performances also provided pretexts to express anti-Semitic attitudes; Buffalo Bill was then compared to a Jew, a thief and a fraud. Journalists also criticized spectators for wasting their money on a "buffoonery run by a foreign fraudster" instead of using them for other purposes like supporting Polish schools. In conclusion, Hlebowicz doubts whether the Polish audience embraced a colonial narrative of the deterioration of the Wilderness that was inscribed in William Cody's project. He is susceptible to claiming that the public rather enjoyed these perfectly organized, colorful and multiethnic shows.

Milan Ducháček discusses the practices of staging, encountering and re-cognizing Slovaks by the Czechs at the Czechoslavic Ethnographic Exhibition in Prague (1895). Therefore, like Barabás, he focuses on 'our own others', who, in that case, were perceived as an 'eastern branch' of the 'Czechoslavic people settled in Bohemia, Moravia, Silesia and (the) Northwest of Hungary'. He reconstructs the Slovak area in the exhibition with native cottages where a small group of people from the Trenčín and Zvolen/Detva regions performed as 'Slovaks' wearing folk costumes, dancing and singing. According to Ducháček, this presentation contributed to the reinforcement of the Czech image of Slovaks as an underdeveloped and poor community; 'unspoiled' by 'western' civilization, yet still resisting Hungarization. The author discusses the changing 'geography of knowledge', the growing incompatibility between the urban and countryside societies and one of the many episodes in the process of forming national identity.

Dániel Molnár explores an uncharted field of variété shows in Berlin in three different socio-political contexts: the Weimar Republic, the NS-Zeit, and the Nachkriegszeit until the Berlin Wall was erected. Drawing on press materials and a huge collection of playbills, posters, programs and other 'show ephemera' (Documenta Artistica housed in Stadtmuseum Berlin) he investigates the activity of three major venues: the Plaza, the Scala and the Wintergarten, also including the Friedrichstadt-Palast which opened after World War II. He is particularly interested in Hungarian themed acts which were quite popular among the German public. He tries to determine the seminal factors of a foreign act which he finds in music, appearance, attire, use of 'typical' objects, invoking 'typical' smells and flavors and not necessarily in the identity of performers. With this primary research paper, Molnár asks basic questions about the popularity of Hungarian-style acts, the German stereotype of the Hungarian performers acting on stage and the Hungarianstyle acts' share in all the foreign-themed acts on the scenes investigated. Therefore, he postulates further detailed research on variété within German culture.

This mosaic of the Central and Eastern European universe of entertainment is supplemented by two papers discussing 'otherness' and entertainment in the regions which do not actually constitute a part of Central and Eastern Europe: Finland and the Russian Empire. We include these essays for two reasons. Firstly, Russia was the 
final destination of many ethnic groups and 'freaks' travelling around Europe in search of profit. This was the case of Julia Pastrana (Morard 2016; 2017), Chang and Eng Bunkers (Wallace - Wallace 1978:288-290), the Ceylonese led by Hagenbeck ${ }^{4}$ and many others (NoviKova 2013). Encounters with 'ethnic others' or those who were 'different' in physical terms, were not unknown to the inhabitants of Kazan, Saint Petersburg and Moscow. On the other hand, the idea of Russia's 'own others' or 'own Orient' is well recognized, following Vera Tolz's decisive publication (Tolz 2011). Oyungerel Tangad, again in this volume, re-orients the discussion towards this group of strangers. However, she does not discuss a temporary presence of itinerant groups, but a permanent presence of Buddhist monks and a Buddhist temple in the very heart of Russia - Saint Petersburg. Tangad looks at the temple's foundation through the lens of the activity of orientalists from the so called Rozen School. As she claims, it was the strong position of Russian Orientalist Studies and the specificity of the national policy of the Russian Empire which accepted and propagated multiculturalism and ethnic diversity that led to the emergence of the Buddhist diaspora in Saint Petersburg. Tangad provides an example of 'otherness' present in the city on a regular basis, forcing citizens to face unknown forms of architecture, prayers and rituals, as well as the comportment of new peoples.

Secondly, Finland's presence in this volume is explained through the country's existence beyond the central sphere of Western Europe, yet still sharing the experience of all Central and Eastern European countries. In terms of the ethnic and freak shows, its situation becomes even more convoluted. Hungary, Germany, Poland, Ukraine, Lithuania and Latvia (current borders) were situated on the way of the troupes to Saint Petersburg and Moscow. Meanwhile, Finland was still beyond those itineraries back in that time. Encounters Finish citizens had with alterity came from within, as in the case of the Saint Petersburg datsan (temple). Anssi Halmesvirta discusses a spectacular episode in the activity of the Finnish Missionary Society: an exhibition of Chinese and African cultures which toured Finland between the years 1926-1928. For the Finnish, it was one of those rare chances to stand face to face with the other. Most interesting, however, are the exhibits, as well as the public's reaction to exhibition scenery. The Society displayed a mannequin representing a 'black' Ovambo man and a real Chinese who was to stand for Chinese contemporary culture in genere. The author also demonstrates how the exhibiting strategies followed the common, one might say, all-European, pattern of uncivilized African and sophisticated, though petrified and bygone Chinese. In pretending to be what they were not, these two 'exhibits' fulfilled both the audiences' and the exhibitors' needs of gathering experiences of the unusual and indeed, of the unknown.

Otherness as a category will never cease to fascinate or intrigue scholars, as it continually asks in-depth questions. The colonial and imperial 'other' that Edward Said's seminal 1978 publication of Orientalism (SAID 1978) made us familiar with, continues to inspire new interpretations, provoking new discussions within the thematic circle he introduced us to. The 'other' that the present volume investigates is of quite a different nature: deprived of the direct flavor of the empire and colony; it resides in, or rather,

${ }_{4}$ Kurjer Warszawski, 1889 no 229 (Sept 20):4; Vilenskii Vestnik, 1891 no 177:1. 
visits, the very eastern borders of the Old Continent. The way that this part of the world, free from (or, maybe, adopting or mimicking?) the filter of the 'imperial eye' - to use Mary L. Pratt's illustrative expression - perceived the 'other' is even more tempting to explore. I hope this volume, with contributions devoted to numerous facets of otherness, will provide insights into how the 'other' was conceptualized, re-worked and assimilated by Central and Eastern European views.

\section{REFERENCES CITED}

AsH, Timothy Garton

1986 Does Central Europe Exist? The New York Review of Books 33(15):45-52.

1999 The Puzzle of Central Europe. The New York Review of Books 46(5):18-23.

BARANIECKA-OlsZEWSKa, Kamila

2020 Buffalo Bill and Patriotism. The Criticism of the Wild West Shows in Polish Press in 1906. East Central Europe (forthcoming).

Blanchard, Pascal - BoËTsch, Gilles - Jacomijn Snoep, Nanette (eds.)

2011 Human Zoos: The Invention of the Savage. Arles: Actes Sud and Paris: Musée du Quai Branly.

BoGDAN, Robert

1988 Freak Show. Presenting Human Oddities for Amusement and Profit. Chicago: Chicago University Press.

Ciarlo, David

2011 Advertising Empire. Race and Visual Culture in Imperial Germany. Cambridge, Mss. \& London: Harvard University Press.

CZARnecka, Dominika

2018 “A w niedzielę szło się oglądać ludzi”. Pokazy etnograficzne we wrocławskim ogrodzie zoologicznym 1876-1930 ["And on Sunday We Went to Watch the People. Ethnographic Shows in the Wrocław Zoological Garden between 1876 and 1930]. Etnografia Polska 62(1-2):183-198.

Demski, Dagnosław

2018 „Spoglądając wstecz”. Wystawa szczepów z Doliny Nilu w Poznaniu, 1914 ["Looking Back". Poznań Exhibition of the Tribes of the Nile Valley, 1914]. Etnografia Polska 62(1-2):199-219.

Filipové, Marta

2011 Peasants on Display: The Czechoslavic Ethnographic Exhibition of 1895. Journal of Design History 24(1):15-36.

GARLAND-ThOMSON, Rosemarie

1997 Extraordinary Bodies. Figuring Physical Disability in American Culture and Literature. New York: Columbia University Press.

2017 Julia Pastrana, the "Extraordinary Lady". Alter - European Journal of Disability Research 11:35-49. 
Herza, Filip

2016 Black Don Juan and The Ashanti from Asch: Representations Of 'Africans' in Prague and Vienna, 1892-1899. In JƯnová Macková, Adéla - STORCHovÁ, Lucie - JŮn, Libor (eds.) Visualising the Orient: Central Europe and the Near East in the $19^{\text {th }}$ and $20^{\text {th }}$ Centuries, 95-106. Prague: Academy of Performing Arts in Prague (AMU) \& Film and TV School of Academy of Performing Arts in Prague (FAMU).

KÉRCHY, Anna - ZitTlau, Andrea (eds.)

2012 Exploring the Cultural History of Continental European Freak Shows and 'Enfreakment'. Newcastle upon Tyne: Cambridge Scholars Publishing.

KŁoczowski, Jerzy (ed.)

2004 Histoire de l'Europe du Centre-Est. Paris: Presses universitaires de France.

Kochanowski, Marek

2010 Miasto jako teatr. Obraz Londynu we wczesnych zapiskach podróżnych Władysława Reymonta [The City as a Theater. The Image of London in Władysław Reymont's Early Travel Accounts]. Białostockie Studia Literaturoznawcze 1:185-201.

KunderA, Milan

1983 Un Occident kidnappé ou la tragédie de l'Europe centrale. Le Débat 5(27):3-22.

KureK, Krzysztof - Meyer, Mateusz

2017 Spacery, koncerty i... „tubylcze wioski”. O (dwuznacznych) przyjemnościach oferowanych w ogrodzie restauracyjnym poznańskiego Zoo w XIX i na początku XX wieku [Walks, Concerts and... 'Tribal Villages'. On (Ambiguous) Amusements Offered by the Restaurant Garden in the Poznań Zoo at the Turn of the $20^{\text {th }}$ Century]. In Guderian-CZAPLiŃSKA, Ewa - KuREK, Krzysztof (eds.) Teatralne przyjemności. Prace ofiarowane Profesor Elżbiecie Kalembie-Kasprzak, 45-59. Poznań: Wydawnictwo UAM.

MORARD, Annick

2016 Julia Pastrana ou les aventures extraordinaires de « la femme-singe » en Russie: Contribution à l'histoire culturelle des spectacles de monstres. [Julia Pastrana, or the Extraordinary Adventures of a "Monkey Woman" in Russia. A Contribution to the Cultural History of Freak Shows]. Cahiers du monde russe 57(4):765-790.

2017 Odomashnit' Inogo. Pokaz monstrov v Rossii [Domesticating the Other. Monster Shows in Russia]. Novoe Literaturnoe Obozrenie. Teoriia $i$ istoriia literatury, kritika i bibliografiia 143:215-232.

Novikova, Irina

2013 Imagining Africa and Blackness in the Russian Empire: from Extratextual Arapka and Distant Cannibals to Dahomey Amazon Shows - Live in Moscow and Riga. Social Identities 19(5):571-591.

QURESHI, Sadiah

2004 Displaying Sara Baartman, the 'Hottentot Venus'. History of Science 42(2):233-257.

REYMONT, Władysław

1894 Dahomejczycy w Berlinie [The Dahomey in Berlin]. Kurier Codzienny 30(207):1. 
SAID, Edward

1978 Orientalism. New York: Pantheon Books.

SZTACHELSKA, Jolanta

1997 “Reporteryje” i reportaże. Dokumentarne tradycje polskiej prozy w 2. pol. XIX i na pocz. XX wieku (Prus - Konopnicka-Dygasiński-Reymont) [Amateur 'Reportages' and Reportages. Documentary Traditions in Polish Prose in the Second Half of the $19^{\text {th }}$ and the Early $20^{\text {th }}$ Century]. Białystok: Wydawnictwo Filii Uniwersytetu Warszawskiego.

Tolz, Vera

2011 Russia's Own Orient. The Politics of Identity and Oriental Studies in the Late Imperial and Early Soviet Periods. Oxford: Oxford University Press.

Wallace, Irving - Wallace, Amy

1978 The Two. The Story of the Original Siamese Twins. London: Cassell.

ZimMERMAN, Andrew

2001 Anthropology and Antihumanism in Imperial Germany. Chicago and London: The University of Chicago Press. 